\title{
Overvåking og forekomst av antibiotikaresistens i Norge
}

\author{
Sammendrag \\ Bakgrunn. Fra 1970-årene har verden \\ sett en økning i antibiotikaresistens \\ blant klinisk viktige mikrober. Den glo- \\ bale utviklingen får betydning også \\ i Norge. I denne artikkelen gis en over- \\ sikt over hvordan den norske overvå- \\ kingen av antibiotikaresistens er bygd \\ opp og hvilke resultater den har gitt \\ de senere årene.
}

\section{Materiale og metode. Artikkelen er basert på egne erfaringer og ikke-sys- tematiske litteratursøk.}

Resultater. Antibiotikaresistens overvåkes gjennom Meldingssystem for smittsomme sykdommer (MSIS), Norsk overvåkingssystem for antibiotikaresistens hos mikrober (NORM) og Det europeiske overvåkingssystemet for antibiotikaresistens (EARSS). Disse systemene og andre enkeltstudier viser at forekomsten av antibiotikaresistens i Norge er lav sammenliknet med andre land, men meticillinresistente Staphylococcus aureus (MRSA), vankomycinresistente enterokokker (VRE), pneumokokker med nedsatt følsomhet for penicillin og gramnegative stavbakterier med særlig bredspektrede betalaktamaser er til stede i den norske bakteriepopulasjonen.

Fortolkning. Overvåkingssystemene for antibiotikaresistens utfyller hverandre og utgjør et viktig redskap i arbeidet mot antibiotikaresistens. Fortsatt overvåking, god laboratoriediagnostikk, fornuftig antibiotikabruk og effektive smitteverntiltak er nødvendig for å forebygge og bekjempe utviklingen av antibiotikaresistens som klinisk problem også i Norge.

\section{Gunnar Skov Simonsen}

gunnar.skov.simonsen@unn.no

NORM - Norsk overvåkingssystem for

antibiotikaresistens hos mikrober

Avdeling for mikrobiologi og smittevern

Universitetssykehuset Nord-Norge 9038 Troms $\emptyset$

Divisjon for smittevern

Nasjonalt folkehelseinstitutt

Oslo

Allerede pionerer som Paul Ehrlich og Alexander Flemming forutså muligheten for at mikrobene kunne utvikle resistens. Gjennom 1950- og 60-årene ble det oppdaget og syntetisert en rekke nye antibiotikagrupper slik at resistensproblemet kunne holdes i sjakk, men fra ca. 1970 har det kommet stadig færre nye originalpreparater på markedet. Det har samtidig skjedd endringer i pasientpopulasjonen med økende alder, behandling med immunosuppressive medikamenter og utstrakt bruk av intravaskulære katetre, ortopediske proteser og andre fremmedlegemer.

Denne utviklingen har ført til høyt forbruk av bredspektrede antibiotika med påfølgende sterk økning av antibiotikaresistens som klinisk problem fra slutten av 1970-årene. Pneumokokker med nedsatt følsomhet for penicilliner og makrolider har fått stor utbredelse $\mathrm{i}$ mange land, og meticillinresistente gule stafylokokker (MRSA) har spredd seg i sykehus over store deler av verden. Gjennom de siste årene har multiresistente gramnegative stavbakterier (Escherichia coli, Klebsiella, Pseudomonas, Acinetobacter m.fl.) utviklet resistens mot nær sagt alle klinisk aktuelle antibiotika (1).

I Norge har forekomsten av resistens vært lav sammenliknet med andre land (2-5). I løpet av 1990-årene erkjente man imidlertid behovet for en mer systematisk og kontinuerlig overvåking på nasjonalt nivå. Jeg vil i denne artikkelen gi en oversikt over hvordan overvåkingen er bygd opp og resultater fra denne overvåkingen og enkeltstående studier om antibiotikaresistens i Norge.

\section{Materiale og metode}

I denne artikkelen har jeg benyttet egne erfaringer som leder av Norsk overvåkingssystem for antibiotikaresistens hos mikrober (NORM) og ikke-systematiske litteratursøk til å beskrive aktuelle overvåkingsopplegg samt gi en oversikt over status for resistens hos viktige bakteriearter i Norge.

\begin{abstract}
Resultater
Overvåking i Norge

Innenfor humanmedisinen er det etablert tre ulike akser for overvåking: Meldingssystem for smittsomme sykdommer (MSIS) (ramme 1), Norsk overvåkingssystem for antibiotikaresistens hos mikrober (NORM) (ramme 2) og Det europeiske overvåkingssystemet for antibiotikaresistens (EARSS) (ramme 3). I det følgende gis en oversikt over enkelte viktige utviklingstrekk basert på blant annet disse systemene.
\end{abstract}

\section{E coli, Klebsiella, Enterobacter og Proteus mirabilis}

Blodkulturisolater av E coli og Klebsiella er generelt følsomme for bredspektrede antibiotika inkludert tredjegenerasjons kefalosporiner, karbapenemer, aminoglykosider og fluorokinoloner (6). Rundt $30 \%$ av E coli er høygradig resistent mot ampicillin. I Norge har man valgt å definere villtypepopulasjonene av E coli og Klebsiella som intermediært følsomme for annengenerasjons kefalosporiner (cefuroksim) for å signalisere at klinisk effekt avhenger av infeksjonsfokus og dosering. Omkring $20 \%$ av E coli-urinveisisolater er resistente mot trimetoprim og trim-sulfa, mens ca. $98 \%$ er følsomme for nitrofurantoin. Det er teknisk vanskelig å resistensbestemme for mecillinam, og det er derfor usikkert hvilken klinisk betydning det har at $8-9 \%$ av E coli-urinveisisolater har redusert følsomhet in vitro. Det er ingen vesentlige forskjeller i resistens mellom isolater fra legekontor, sykehjem og sykehus.

Ampicillin kan ikke brukes mot Klebsiella eller Enterobacter på grunn av iboende betalaktamaseaktivitet. Klebsiella er mer resistent enn E coli overfor nitrofurantoin (ca. 30\% resistens) mens Enterobacter er mer følsom for trimetoprim (ca. $10 \%$ resistens) (6). P mirabilis er følsom for de fleste

\section{Hovedbudskap}

- Overvåkingssystemene for antibiotikaresistens utfyller hverandre

- Norge har lav forekomst av antibiotikaresistens sammenliknet med andre land

- Fortsatt overvåking, god mikrobiologisk diagnostikk, nøktern antibiotikabruk og effektive smitteverntiltak er avgjørende for å bevare den gunstige situasjonen 


\section{Ramme 1}

\section{Meldingssystem for smittsomme sykdommer (MSIS)}

MSIS er et kombinert laboratoriebasert og klinisk overvåkingssystem der hvert enkelt tilfelle av definerte infeksjonssykdommer skal meldes enten nominativt eller summarisk til Folkehelseinstituttet. Datainnsamlingen er lovpålagt og regulert i MSIS- og tuberkuloseregisterforskriften hjemlet i Helseregisterloven.

Allerede fra opprettelsen i 1977 har MSIS registrert resistens mot betalaktamantibiotika og senere også fluorokinoloner hos Neisseria gonorrhoeae. Man har tilsvarende fra 1975 inkludert resistensdata for Mycobacterium tuberculosis i Tuberkuloseregisteret. Laboratoriene har meldt inn resultater fra den rutinemessige resistensbestemmelsen uten spesifikke krav til valg av analysemetoder. Overvåking av resistens blant hivinfeksjoner ble startet i 2006.

Fra 1995 har MSIS også etablert kasusbasert overvåking av infeksjon med meticillinresistente gule stafylokokker, vankomycinresistente enterokokker og penicillinresistente Streptococcus pneumoniae, og fra 2005 er også bærertilstand av disse mikrobene inkludert. Ettersom man registrerer alle tilfeller, rapporteres totalantall eller rate ut fra befolkningsgrunnlag (www.msis.no)

urinveisantibiotika unntatt trimetoprim (ca. $25 \%$ resistens) og nitrofurantoin (iboende resistens). Det er økende problemer med resistens forårsaket av særlig bredspektrede betalaktamaser (ESBL, AmpC og MBL) (1-6). Situasjonen for gramnegative tarmbakterier er videre preget av økende resistens mot fluorokinoloner $(7,8)$. Andelen av E coli-blodkulturisolater med nedsatt følsomhet for eller resistens mot ciprofloksacin har økt hvert år siden 2000 og lå i 2007 på $8,9 \%$, og dette avspeiler det økende forbruket av ciprofloksacin (fig 1). Det er også påvist resistens mot ciprofloksacin blant E coli-urinveisisolater (4,7\% ikke-følsomme), Klebsiella-blodkulturisolater $(9,5 \%$ ikke-følsomme) og P mirabilis-urinveisisolater (2,4 \% ikke-følsomme i 2006) (6).

\section{Pseudomonas aeruginosa}

$\mathrm{P}$ aeruginosa har iboende nedsatt følsomhet for flere klasser av antibiotika samt en unik evne til å erverve resistens og tilpasse seg miljøer med høyt antibiotikaforbruk. Den er derfor en fryktet mikrobe ved intensivavdelinger og andre enheter som behandler kritisk syke og immunsupprimerte pasienter (9). Gjennom Norsk overvåkingssystem for antibiotikaresistens hos mikrober undersøkte man alle norske blodkulturisolater av
P aeruginosa i perioden 2002-03, og forekomsten av ervervet resistens var meget lav. Det ble ikke påvist resistens mot aminoglykosider (tobramycin), og de aller fleste isolatene var følsomme for aktuelle betalaktamer. Man har imidlertid sett en økende forekomst av nedsatt følsomhet for karbapenemer gjennom Det europeiske overvåkingssystemet for antibiotikaresistens, der rundt $15 \%$ av systemiske isolater fra Norge nå rapporteres som ikke-følsomme. Dette skyldes først og fremst seleksjon av mutasjonsbasert resistens, men det er også påvist flere importerte isolater med ervervede metallobetalaktamaser (10).

\section{Haemophilus influenzae}

og Moraxella catarrhalis

$\mathrm{H}$ influenzae var tidligere årsak til meningitt, epiglottitt og sepsis, men etter innføringen av Hib-vaksinen ses nå hovedsaklig lokaliserte luftveisinfeksjoner. Betalaktamaseproduksjon i $\mathrm{H}$ influenzae fører til resistens mot penicilliner, mens mutasjoner i penicillinbindende proteiner (PBP) i tillegg kan medføre nedsatt følsomhet for kefalosporiner og eventuelt karbapenemer. I 2007 var $10,5 \%$ av $\mathrm{H}$ influenzae fra luftveisprøver betalaktamasepositive, mens $8,0 \%$ også var resistente mot kombinasjonen av ampicillin og betalaktamasehemmeren klavulansyre (6). Det er ikke holdepunkter for ervervet resistens mot makrolider og tetrasykliner hos $\mathrm{H}$ influenzae, men rundt $15-20 \%$ av de norske isolatene er resistente mot trimetoprim-sulfa.

Over $90 \%$ av M catarrhalis-luftveisisolater produserer betalaktamase og er resistente mot penicilliner (penicillin $\mathrm{G}$, penicillin $\mathrm{V}$, amoksicillin, ampicillin), men for øvrig er denne bakteriearten følsom for relevante perorale antibiotika som makrolider, tetrasykliner og trimetoprim-sulfa.

\section{Tarmpatogener}

Tarmpatogene bakterier som overføres fra dyr overvåkes i prøver fra fôr, produksjonsdyr, matvarer og mennesker. Bakterieisolater fra mennesker har resistensegenskaper avhengig av smittested. Dersom man blir smittet av Campylobacter eller Yersinia enterocolitica fra norske smittekilder, vil forekomsten av antibiotikaresistens være vesentlig lavere enn blant isolater fra utlandet. Infeksjoner med Salmonella og Shigella skyldes oftest utenlandssmitte, og resistensforholdene vil da gjenspeile situasjonen i opphavslandet. Overvåkingsdata fra 2007 viser at Salmonella typhimurium fra Norge har varierende grad av resistens mot ampicillin $(26,9 \%)$, kloramfenikol $(10,8 \%)$ og tetrasyklin $(26,9 \%)$, men er vanligvis følsom for trimetoprim-sulfa $(91,5 \%)$ og ciprofloksacin $(95,4 \%)$ (6). Bortsett fra ciprofloksacin (1,4\% resistens) ligger andelen resistente isolater vesentlig høyere for alle midlene hos isolater av $\mathrm{S}$ typhimurium assosiert til utenlandssmitte. Campylobacter jejuni med innenlandsk smitte er vanligvis følsom for alle

\section{Ramme 2}

\section{Norsk overvåkingssystem for antibiotikaresistens hos mikrober (NORM)}

Det sentrale NORM-registeret reguleres av NORM-forskriften hjemlet i helseregisterloven. Universitetssykehuset Nord-Norge er systemets databehandler, mens Folkehelse instituttet er databehandlingsansvarlig. Det overordnede formålet er å fremme kvaliteten på forebyggende tiltak mot antibiotikaresistens og helsehjelp som tilbys og ytes mot infeksjonssykdommer. Dette skal man oppnå ved å kartlegge forekomst, utbredelse og endringer over tid. Man skal også drive, fremme og gi grunnlag for forskning om årsaker til resistensutvikling og etablere kunnskap for rådgivning og informasjon til forvaltningen, helsetjenesten og befolkningen. Overvåkingssystemet skal gi norske myndigheter grunnlag til å bidra til internasjonal statistikk innenfor resistensområdet. Det har i fagmiljøet vært bred enighet om at formålene bare kunne oppnås gjennom et standardisert nasjonalt overvåkingssystem med høyt kvalitetsnivå.

NORM er organisert som et nettverk av medisinsk mikrobiologiske laboratorier som på frivillig basis bidrar til overvåkingen. Det kan ikke kontinuerlig overvåke alle aspekter av resistensproblematikken. Dette skyldes dels omfanget av mikrobiologisk diagnostikk og resistensbestemmelse rundt omkring i landet, dels behovet for enhetlig kvalitet og de innsamlede datas sammenliknbarhet. Den rutinemessige resistensbestemmelsen utføres på ulike måter ved landets laboratorier mht. valg av antibiotika, identifikasjonskrav til mikrobeisolatene, testmetoder, utstyrsleverandører og lokal organisering av virksomheten.

Fra starten ble det etablert felles metoder slik at data kunne sammenstilles i nasjonal statistikk. Man vil over tid bidra til standardisering av resistensbestemmelsen, slik at rutinedata i større grad kan brukes.

Registeret prioriterer å overvåke resistens hos klinisk viktige mikrober som fører til alvorlig sykdom eller infeksjoner med få aktuelle behandlingsalternativer, mikrober der man frykter resistensutvikling eller der resistens er påvist i andre land, mikrober knyttet til næringsmidler eller import fra andre land, og mikrober som lett erverver resistens og dermed gir signal om uheldig seleksjonspress. Overvåking av resistens mot klinisk viktige antibiotika og mot antibiotika som kan gi tidlig signal om resistensutvikling, blir vektlagt.

Fagrådet vurderer fortløpende overvåkingsopplegget ut fra den epidemiologiske situasjonen i Norge og andre land. Man har valgt å undersøke blodkulturisolater av E coli, Klebsiella, Streptococcus pneumoniae, Enterococcus faecalis, Enterococcus faecium og $\mathrm{S}$ aureus hvert år, mens andre mikrober og isolater fra andre kliniske materialer blir inkludert etter behov.

NORM utgir i samarbeid med det veterinære overvåkingssystemet NORM-VET årlige rapporter om bruk av antibiotika og forekomst av resistens i Norge (www.antibiotikaresistens.nol.

I likhet med øvrige helseregistre har NORM utleveringsplikt innenfor gitte tidsfrister. Søknader rettes til NORM sentralt som i samråd med fagrådet gir tilgang til datauttrekk. 
aktuelle antibiotika, mens man ved utenlandssmitte ser betydelig forekomst av resistens mot tetrasyklin $(49,3 \%)$ og ciprofloksacin $(57,4 \%)$ (6). Resistensforholdene hos Shigella avhenger av bakterieart.

\section{Staphylococcus aureus}

I Norge produserer ca. $75 \%$ av $\mathrm{S}$ aureus (gule stafylokokker) betalaktamase som inaktiverer vanlig penicillin, men betalaktamasestabile penicilliner vil fortsatt være aktive. Meticillinresistente gule stafylokokker (MRSA) uttrykker et alternativt penicillinbindende protein, slik at bakteriene er resistente mot alle betalaktamantibiotika inkludert kefalosporiner og karbapenemer. Antallet rapporterte tilfeller av MRSA-infeksjoner og -bærertilstander har økt de siste årene, men utgjør fortsatt en meget liten andel av det totale antallet gule stafylokok$\operatorname{ker}(<1 \%)(11)$

$\mathrm{S}$ aureus-blodkulturisolater er generelt følsomme ( $>95 \%)$ for alle aktuelle antibiotika til behandling av systemiske infeksjoner. Det forekommer enkelte isolater med resistens mot makrolider (erytromycin), linkosamider (klindamycin) og fluorokinoloner (ciprofloksacin), mens nesten alle isolater er følsomme for aminoglykosider (gentamicin), trimetoprim-sulfa og rifampicin Det er ikke påvist resistens mot vankomycin eller linezolid (6).

Man har i de siste årene sett en høy forekomst av resistens mot fusidinsyre blant isolater fra hud- og bløtdelsinfeksjoner (25,0\% i 2004). Dette skyldes smittespredning av en epidemisk internasjonal fusidinresistent klon som forårsaker impetigo bullosa, spesielt blant barn på ettersommeren og tidlig på høsten (12). Andelen av fusidinresistente blodkulturisolater har ikke oversteget $8 \%$, og utbredelsen av den aktuelle klonen er nå på retur, med $11,1 \%$ resistens blant isolater fra hud- og bløtdelsinfeksjoner i 2007 (6).

\section{Streptococcus pneumoniae}

Pneumokokker med nedsatt følsomhet for eller resistens mot penicillin og eventuelt kefalosporiner er et stort folkehelseproblem i mange land. I Norden har man hatt utbrudd av internasjonale resistente kloner på Island og i Sør-Sverige. Resultater fra Norsk overvåkingssystem for antibiotikaresistens hos mikrober og Det europeiske overvåkingssystemet for antibiotikaresistens viser at $2-3 \%$ av invasive pneumokkisolater fra Norge har nedsatt følsomhet for penicillin, og blant disse er kun spredte enkeltisolater høygradig penicillinresistente med samtidig nedsatt følsomhet for kefalosporiner. Andelen luftveisisolater med nedsatt følsomhet for penicillin er noe høyere (3,3\% i 2007) og viser en økende tendens (6).

Andelen invasive isolater med nedsatt følsomhet for erytromycin økte fra $2 \%$ i 2000 til $12,4 \%$ i 2006 (fig 2). Dette skyldes i all hovedsak utbredelse av en internasjonal klon med serotype 14 som bærer effluks- egenskaper kodet av mefA-genet $(13,14)$. Man har i tillegg registrert økende forekomst av erm-gener som koder for endring av målmolekylet for makrolider og klindamycin. Serotype 14 er inkludert i den konjugerte pneumokokkvaksinen, og med 9,4\% erytromycinresistens i $2007 \mathrm{kan}$ man derfor håpe at spredningen av makrolidresistens kan stanses. Man vet ikke hvorfor forekomsten av makrolidresistens har vært lavere blant luftveisisolater ( $8,0 \%$ i 2007) (6).

\section{Streptococcus pyogenes}

og Streptococcus agalactiae

$\mathrm{S}$ pyogenes (betahemolytiske streptokokker gruppe A) og S agalactiae (betahemolytiske streptokokker gruppe B) er alltid følsomme for penicilliner, men i likhet med pneumokokker har man sett spredning av makrolidresistente kloner (15). I Norge er andelen av makrolidresistente $\mathrm{S}$ pyogenes i blodkulture under $1 \%$, mens den er noe høyere for isolater fra halsprøver (3,2\% i 2006). De fleste invasive gruppe B-streptokokker er følsomme for makrolider, men et utbrudd i tilknytning til nyfødtavdelinger i 2006 skyldtes en makrolidresistent stamme $(15,16)$.

\section{Enterococcus faecalis}

\section{og Enterococcus faecium}

E faecalis og E faecium kan forårsake urinveisinfeksjoner, endokarditt og intraabdominale infeksjoner. E faecium ses ofte ved sepsis hos pasienter med alvorlig underliggende sykdom. Enterokokker er en infeksjonsmedisinsk utfordring, da de i utgangspunktet har naturlig nedsatt følsomhet for mange antibiotikagrupper. De har i tillegg stor evne til å erverve resistens fra omgivelsene. Det kan være svært vanskelig å finne effektive behandlingsalternativer mot multiresistente stammer.

I Norge er enterokokkinfeksjoner tradi-

\section{Ramme 3}

\section{Det europeiske overvåkingssystemet} for antibiotikaresistens (EARSS)

NORM ivaretar Norges deltakelse i Det europeiske overvåkingssystemet for antibiotikaresistens som administreres av det europeiske smitttevernsenteret (ECDC). EARSS inkluderer kategoriserte rutinedata for systemiske isolater fra blod og spinalvæske av E coli, $\mathrm{K}$ pneumoniae, $P$ aeruginosa, $S$ aureus, $S$ pneumoniae, $E$ faecalis og $E$ faecium. Omtrent halvparten av norske mikrobiologiske laboratorier leverer kvartalsvise data (www.rivm.nl/earss). Sammenstilte data fra de norske deltakerlaboratoriene publiseres gjennom MSIS-rapporter.

sjonelt blitt behandlet med en kombinasjon av ampicillin og et aminoglykosid. Ved penicillinallergi har man byttet ut ampicillin med vankomycin. E faecalis er nesten alltid følsom for ampicillin, men andelen ampicillinresistente $\mathrm{E}$ faecium har $ø \mathrm{kt}$ dramatisk over de siste ti årene og var i 2007 på 79,5 \% (6). Dette skyldes sannsynligvis utbredelse av den internasjonale sykehustilpassede $\mathrm{CC}$ 17-klonen som i andre land ofte er resistent mot kinoloner, ampicillin og vankomycin $(17,18)$. Andelen av høygradig gentamicinresistens var 30,4\% hos E faecalis og 55,1\% hos E faecium i 2007 (fig 3). Det er kun påvist spredte enkeltisolater av enterokokker med klinisk relevant vankomycinresistens.

\section{Diskusjon}

I Norge er det etablert flere ulike overvåkingssystemer for å kunne forebygge og bekjempe antibiotikaresistens. Systemene har

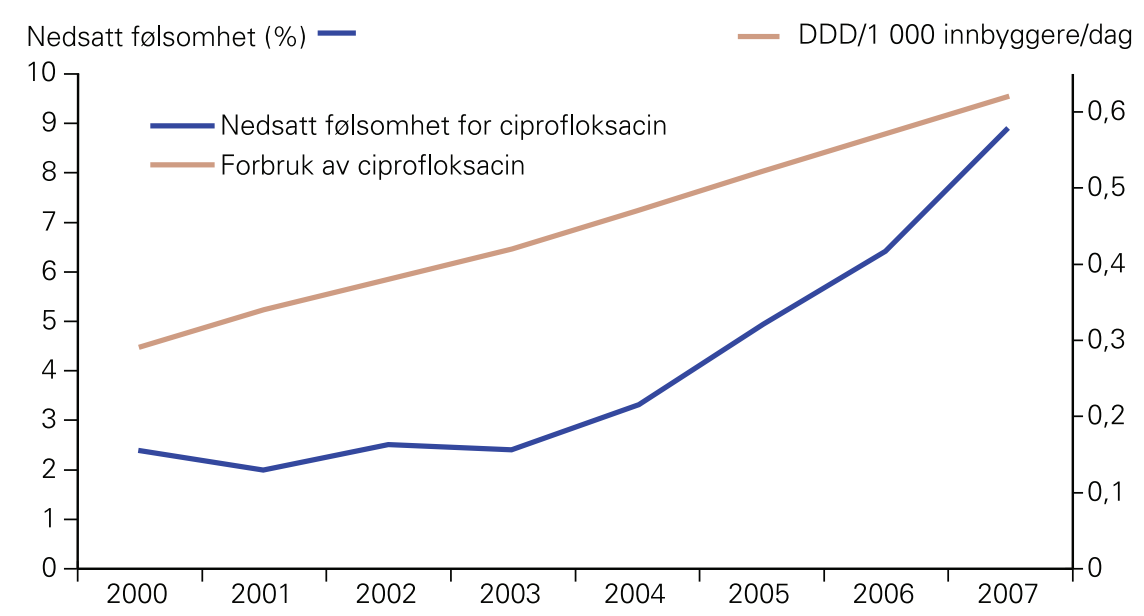

Figur 1 Andel (\%) Escherichia coli-blodkulturisolater med redusert følsomhet for ciprofloksacin (blå kurve) og forbruk av ciprofloksacin (gul kurve) 2000-07. Figuren er basert på brytningspunktene for ciprofloksacin gjeldende fra mars 2008. Figur basert på NORM/NORM-VET 2007 (6), med tillatelse 


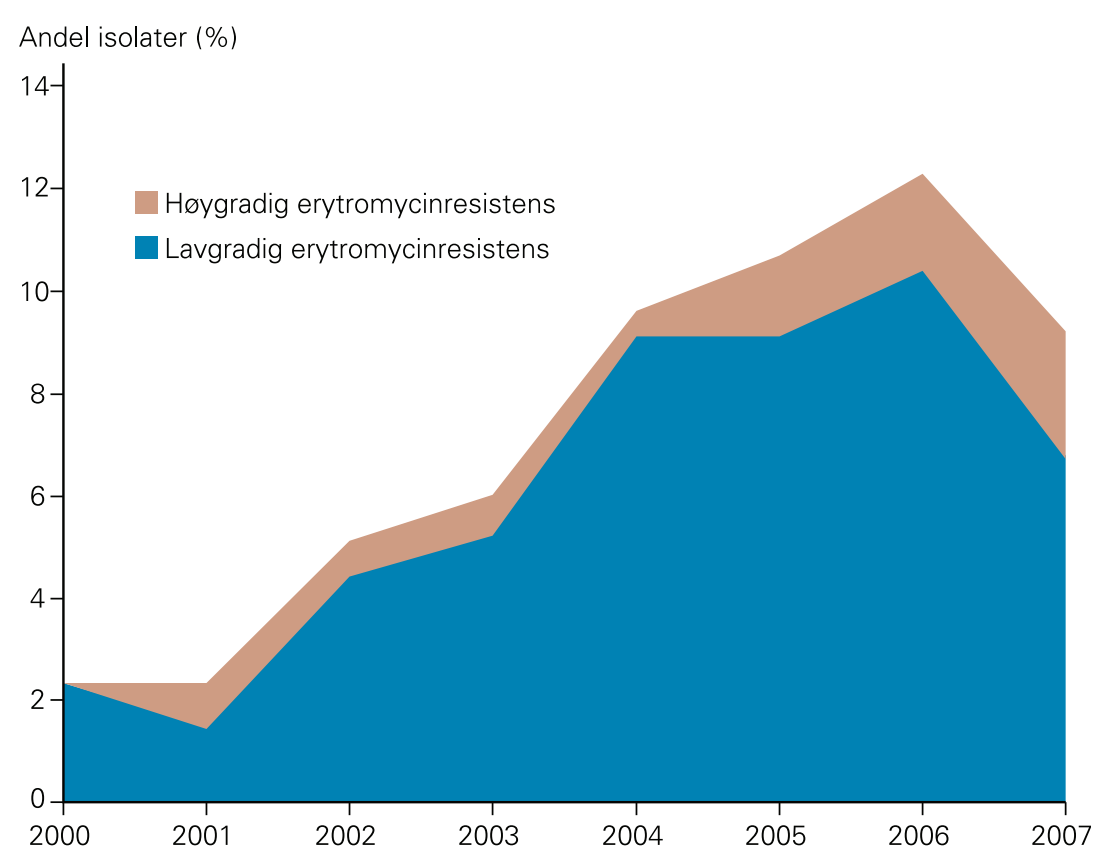

Figur 2 Andel (\%) av Streptococcus pneumoniae-blodkulturisolater med lavgradig og høygradig resistens mot erytromycin i 2000-07. Figur basert på NORM/NORM-VET 2007 (6), med tillatelse

fordeler og ulemper, men utfyller hverandre og utgjør et viktig redskap i arbeidet mot antibiotikaresistens.

\section{Dagens overvåking}

Den kasusbaserte overvåkingen i Meldingssystem for smittsomme sykdommer fungerer best ved sjeldne tilstander der laboratoriene følger ensartede prosedyrer for prøvehåndtering, identifikasjon og resistensbestemmelse. Ved å innhente klinisk informasjon kan man få god oversikt over smittereservoarer, smitteveier, risikofaktorer og behandlingsresultater.
Fordelen med Det europeiske overvåkingssystemet for antibiotikaresistens er at det benytter rutinedata og følgelig ikke forutsetter ytterligere mikrobiologiske undersøkelser. Man får forløpende presentert data fra hele Europa. Svakheten er at kvalitetssikringen kun består i utsending av eksterne kvalitetskontrollstammer, og at registreringen baserer seg på kategoriserte data uten bruk av ensartede brytningspunkter eller mikrobiologiske metoder. Det er også en begrensning at man ikke inkluderer isolater fra lokaliserte infeksjoner selv om slike tilstander er de dominerende indikasjonene for forskrivning av anti-

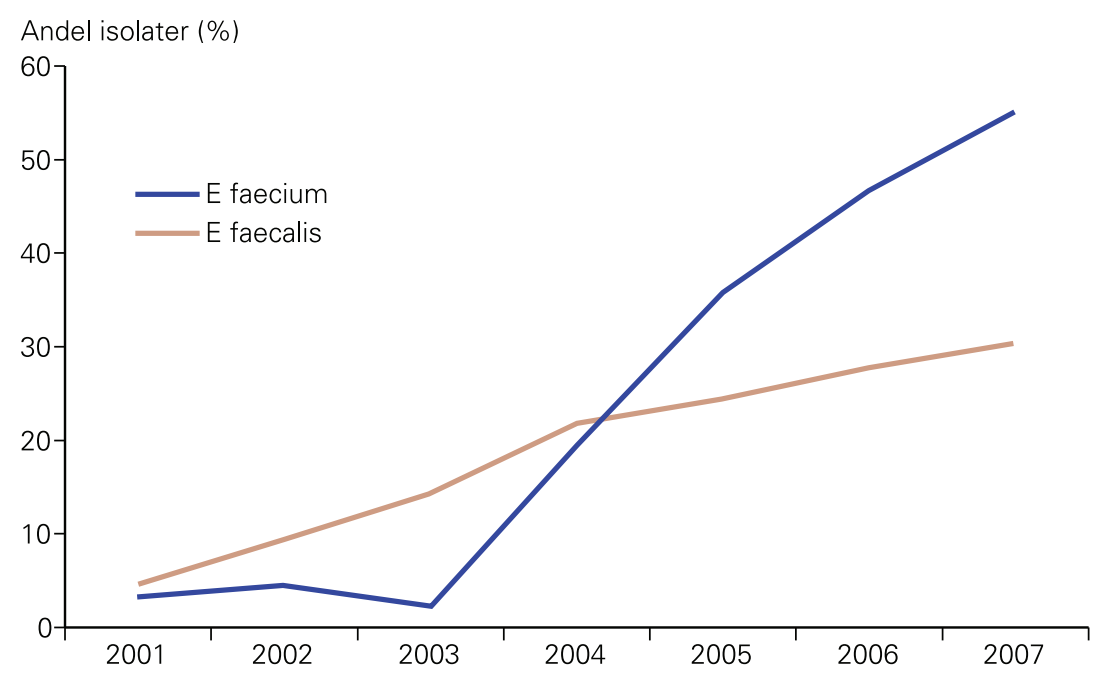

Figur 3 Andel (\%) av Enterococcus faecalis-og Enterococcus faecium-blodkulturisolater med høygradig gentamicinresistens 2000-07. Data fra NORM/NORM-VET 2007 (6)

biotika. Årsaken til at man ikke inkluderer ikke-invasive isolater, er de store variasjonene i diagnostisk praksis mellom deltakerlandene. Ved lav prøvetakingsfrekvens vil man oftest inkludere isolater ved klinisk behandlingssvikt, hvilket fører til svært høy prevalens av resistens. I de nordiske landene bidrar finansieringsordningen for laboratorietjenester til høy prøvetakingsfrekvens og følgelig lavere forekomst av resistens. Det europeiske overvåkingssystemet for antibiotikaresistens forutsetter at denne effekten er mindre uttalt ved alvorlige systemiske infeksjoner.

Bakgrunnen for valget av frivillig deltakelse i Norsk overvåkingssystem for antibiotikaresistens hos mikrober er at kravene til datakvalitet er så omfattende at pliktmessig innmelding av rutinedata ikke har vært ansett som formålstjenlig. Helt fra etableringen har systemet i samarbeid med Arbeidsgruppen for antibiotikaspørsmål (AFA) og Kompetansesenteret for påvisning av antibiotikaresistens (K-res) utformet overvåkingsaktivitetene som et kvalitetsbyggende prosjekt for det medisinskmikrobiologiske fagmiljøet. Denne fremgangsmåten har vært vellykket, og fra 2002 har alle aktuelle laboratorier ønsket å delta i systemet. Nettverksmodellen vedlikeholdes gjennom regelmessige møter mellom et sentralt organ og et fagråd sammensatt av representanter for dataleverandører (laboratoriene) og aktuelle databrukere (infeksjonsmedisinere, allmennmedisinere, Folkehelseinstituttet).

Det er av stor betydning at Norsk overvåkingssystem for antibiotikaresistens hos mikrober også omfatter isolater fra lokaliserte infeksjoner i luftveier, hud og urinveier. Dette skyldes at ulike bakteriekloner kan forekomme ved spesielle kliniske tilstander, og resistensforhold kan derfor variere ut fra klinisk prøvemateriale. Det er også viktig at man overvåker antibiotika med spesiell relevans ved gitte kliniske indikasjoner, f.eks. pivmecillinam og nitrofurantoin ved urinveisinfeksjoner forårsaket av $\mathrm{E}$ coli. Utvalget av antibiotika revurderes hvert år. I tillegg til det opprinnelige fokus på humanpatogene bakterier har man de siste årene også presentert resistensdata for gjærsopp og hiv.

Flere forskningsprosjekter har benyttet isolater og informasjon fra Norsk overvåkingssystem for antibiotikaresistens hos mikrober som grunnlag for videre epidemiologiske og mikrobiologiske studier $(13,15$, 19). Interesserte forskere kan bidra til utformingen av fremtidige overvåkingsopplegg og på den måten bruke Norsk overvåkingssystem for antibiotikaresistens hos mikrober som et verktøy for nasjonale multisenterstudier innen antibiotikaresistens. Ulempen ved den valgte strategien er at den er ressurskrevende både for deltakerlaboratoriene og for registeret sentralt.

Utfordringer ved overvåkingen

Det har vært argumentert for at all laboratoriebasert resistensovervåking er uegnet som 
grunnlag for valg av empirisk terapi (20). I Norge er det for eksempel ikke anbefalt å sende urinveisprøver til dyrking og resistensbestemmelse ved ukomplisert nedre urinveisinfeksjon hos kvinner i fertil alder. Resistensdata basert på innsendte prøver er derfor ikke veiledende for den empiriske førstelinjebehandlingen. Bærheim og medarbeidere undersøkte denne effekten og fant blant annet en forskjell mellom innsendte isolater og alle isolater på 5,0\% for amoksicillin, $5,6 \%$ for trimetoprim og $6,7 \%$ for nitrofurantoin (21).

Det har vært foreslått at man heller burde etablere vakttårnssystemer der man i perioder tar prøve av alle pasienter med en gitt infeksjonstilstand (22). Man har svært begrensede erfaringer med en slik populasjonsbasert strategi, og det er usikkert om utbyttet vil stå i rimelig forhold til innsatsen.

En annen feilkilde ved tradisjonell resistensovervåking er at man vanligvis angir andel av en bakterieart som har en bestemt resistensegenskap. Man vil imidlertid ikke registrere økologiske forskyvninger fra naturlig følsomme bakteriearter til mikrober med iboende resistensegenskaper. For å korrigere denne effekten publiserer Norsk overvåkingssystem for antibiotikaresistens hos mikrober årlige oversikter over artsfordelingen for alle blodkulturisolater ved norske laboratorier.

\section{Situasjonen i Norge}

Forekomsten av resistens er lav i Norge sammenliknet med de fleste andre land. Det er derfor spesielt viktig å unngå spredning av meticillinresistente $\mathrm{S}$ aureus, pneumokokker med nedsatt følsomhet for penicillin, vankomycinresistente enterokokker og gramnegative stavbakterier med særlig bredspektrede betalaktamaser. På flere områder ser man imidlertid en urovekkende økning av resistensproblemene i klinisk viktige mikrober. Det er derfor nødvendig med fornyet fokus på god laboratoriediagnostikk, rasjonell antibiotikabruk og effektive smittevernstiltak.

Oppgitte interessekonflikter: Ingen

\section{Litteratur}

1. Sundsfjord A, Simonsen GS, Haldorsen B et al. Bredspektrede betalaktamaser hos gramnegative stavbakterier. Tidsskr Nor Legeforen 2008; 128: 2741-5.

2. Rollag H, Midtvedt T, Hovig B et al. Sensitivity patterns of bacteria and antibiotic usage at the National Hospital of Norway in 1976 and 1978. Zentralb. Bakteriol [Orig A] 1979; 244: 515-24.

3. Vorland LH, Carlson K, Aalen O. Antibiotic resistance and small R plasmids among Escherichia coli isolates from outpatient urinary tract infections in northern Norway. Antimicrob Agents Chemother 1985; 27: 107-13.

4. Haug JB, Harthug S, Kalager T et al. Bloodstream infections at a Norwegian university hospital, 1974-1979 and 1988-1989: changing etiology, clinical features, and outcome. Clin Infect Dis 1994: 19: 246-56

5. Bergan T, Gaustad P. Høiby EA et al. Antibiotic resistance of pneumococci in Norway. Int J Antimicrob Agents 1998; 10: 77-81.

6. NORM/NORM-VET 2007. Usage of antimicrobial agents and occurrence of antimicrobial resistance

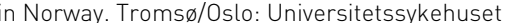
Nord-Norge og Veterinærinstituttet, 2008.

7. Grude N, Strand L, Mykland $\mathrm{H}$ et al. Fluoroquinolone-resistant uropathogenic Escherichia coli in Norway: evidence of clonal spread. Clin Microbiol Infect 2008; 14: 498-500.

8. Grude N, Tveten Y, Jenkins A et al. Uncomplicated urinary tract infections. Bacterial findings and efficacy of empirical antibacterial treatment. Scand J Prim Health Care 2005: 23. 115-9.

9. Iversen BG, Jacobsen T, Eriksen HM et al. An outbreak of Pseudomonas aeruginosa infection caused by contaminated mouth swabs. Clin Infect Dis 2007: 44: 794-801.

10. Samuelsen O, Buarø L, Giske CG et al. Evaluation of phenotypic tests for the detection of metallobeta-lactamase-producing Pseudomonas aeruginosa in a low prevalence country. J Antimicrob Chemother 2008: 61: 827-30.

11. Elstrøm P, Aavitsland P. Meticillinresistente gule stafylokokker i Norge. Tidsskr Nor Legeforen 2008; 128: 2730-3.
12. Tveten $Y$, Jenkins A, Kristiansen BE A fusidic acidresistant clone of Staphylococcus aureus associated with impetigo bullosa is spreading in Norway. J Antimicrob Chemother 2002; 50: 873-6.

13. Littauer P. Sangvik M, Caugant DA et al. Molecular epidemiology of macrolide-resistant isolates of Streptococcus pneumoniae collected from blood and respiratory specimens in Norway. J Clin Microbiol 2005; 43: 2125-32.

14. Sogstad MK, Littauer P, Aaberge IS et al. Rapid spread in Norway of an erythromycin-resistant pneumococcal clone, despite low usage of macrolides. Microb Drug Resist 2007; 13: 29-36.

15. Littauer P, Caugant DA, Sangvik M et al. Macrolide-resistant Streptococcus pyogenes in Norway: population structure and resistance determinants Antimicrob Agents Chemother 2006; 50: 1896-9.

16. Hajdu A, Blystad H, Høiby EA et al. Unexpected increase in case fatality of invasive group $B$ streptococcal infections in infants in Norway, January-July 2006. Euro Surveill 2006; 11: E060727.2.

17. Simonsen GS, Småbrekke L, Monnet DL et al. Prevalence of resistance to ampicillin, gentamicin and vancomycin in Enterococcus faecalis and Enterococcus faecium isolates from clinical specimens and use of antimicrobials in five Nordic hospitals. J Antimicrob Chemother 2003: 51: 323-31.

18. Jureen R, Top J, Mohn SC et al. Molecular characterization of ampicillin-resistant Enterococcus faecium isolates from hospitalized patients in Norway. J Clin Microbiol 2003; 41: 2330-6.

19. Tofteland S, Haldorsen B, Dahl KH et al. Effects of phenotype and genotype on methods for detection of extended-spectrum-beta-lactamase-producing clinical isolates of Escherichia coli and Klebsiella pneumoniae in Norway. J Clin Microbiol 2007: 45: 199-205.

20. Schwaber MJ, De-Medina T, Carmeli Y. Epidemiological interpretation of antibiotic resistance studies - what are we missing? Nat Rev Microbiol 2004: 2: 979-83.

21. Bærheim A, Digranes A, Hunskaar S. Are resistance patterns in uropathogens published by microbiological laboratories valid for general practice? APMIS 1999; 107: 676-80.

22. Hillier S, Bell J, Heginbothom M et al. When do general practitioners request urine specimens for microbiology analysis? The applicability of antibiotic resistance surveillance based on routinely collected data. J Antimicrob Chemother 2006; 58: 1303-6.

Manuskriptet ble mottatt 29.6. 2008 og godkjent 17.2. 2009. Medisinsk redaktør Preben Aavitsland. 